\title{
Using benthic diatoms for estimating lake ecological quality: Comparing different taxonomic resolution
}

\author{
Aldo Marchetto, ${ }^{*}$ Tommaso Sforzi \\ CNR-ISE Institute of Ecosystems Study, Largo Tonolli 50, 28922 Verbania Pallanza, VB, Italy \\ *Corresponding author: a.marchetto@ise.cnr.it
}

\begin{abstract}
The Water Framework Directive asks to all Member States of the European Union to classify the ecological quality of significant waterbodies on the basis of the biological communities they host. One of the biological communities that must be used for the ecological quality assessment is the periphytic community, mainly composed by diatoms. In Italy, diatom-based lake quality assessment is performed using a specific index, named EPI-L, based on the method of weighted averages. For each species, a trophic score and an indicator weight were calculated. In order to reduce the complexity of the lake quality assessment, we calibrated a variant of EPI-L, using diatoms genera instead of species, and we compared the performance of these two variants in terms of correlation with the nutrient level and of different classification of each lake.
\end{abstract}

Key words: Diatoms; WFD; lakes.

Received: March 2018. Accepted: June 2018.

\section{INTRODUCTION}

The European Union's Water Framework Directive (WFD; European Union 2000) requires the management of surface water body in order to achieve (or maintain) at least good chemical and ecological status. Good ecological status is defined as a slight deviation from the ecological status normally associated with the same surface water body type under undisturbed conditions. According to annex 5 of the WFD, the ecological status should be evaluated using the so-called Biological Quality Elements (BQEs), which include fish, invertebrates, macrophytes and phytobenthos, and phytoplankton. For each $\mathrm{BQE}$, the value of a quality index should be compared to a reference value indicating minimal human impact to obtain an ecological quality ratio. Macrophytes and phytobenthos are components of freshwater flora and are included by Annex 5 of the WFD in a single BQE, but they are evaluated separately, as they can respond differently to human impact, in relation to site-specific conditions (Schneider et al., 2012; Kelly et al., 2016).

Within phytobenthos, diatoms are considered the most representative component and are commonly used for the evaluation of the ecological status of both lotic and lentic waterbodies.

Since the pioneering work by Sladecek (1984), diatoms have been largely used for the evaluation of river quality. Among the methods used in Europe, Kelly et al. (2014) distinguish three types: indices based on the weighted average equation of Zelinka and Marvan (1961) and optimised against a stressor gradient, indices based on the relative proportion of taxa associated with unimpacted and impacted conditions, and multimetric indices based on a combination of these approaches. In the oldest indices, species were grouped on the basis of their tolerance or sensitivity to pollution, and river quality was estimated on the basis of the proportion of tolerant and sensitive taxa. More recent indices, such as IPS (CEMAGREF, 1982), Trophic Diatom Index (TDI, Kelly and Whitton, 1995) and the Diatom Biological Index (BDI, Coste et al., 2009), are based on a weighted average equation (Zelinka and Marvan, 1961) and make use of ecological information for each species, obtained from a calibration data set. During the calibration, each species is assigned a value indicating the sensitivity or tolerance of that species to a specific form of pollution, and an optional value indicating the indicator value of that species.

The development of specific indices for the evaluation of lake ecological quality (Rott, 1999; Schaumburg et al., 2004; Flemish Environment Agency, 2009; Bennion et al., 2014) is more recent.

Most indices using diatoms for evaluating the ecological quality of lakes are based on the trophic preferences of single species. This approach may cause two difficulties: on one hand, the large number of diatom species requires intensive training of the personnel performing the analysis and species misidentification can occur; on the other hand, a given index cannot be used when the sample is rich in species that are not included in 
the list that was defined when setting up the index.

Most indices were developed in the 1990s, when diatom species were grouped in large, heterogeneous genera. In the last decades, a large revision of diatoms taxonomy has occurred (Round et al., 1990), splitting genera with a large number of species into smaller units, morphologically more homogenous. Although it can be expected that species belonging to smaller and probably more genetically homogenous genera would also have closer ecological preferences, it is possible that the new genera still include species with large ecological differences.

In this paper, we test the possibility to develop an index using diatom genera instead of species, for reducing the effort and the cost needed for the routine ecological classification of lakes and reservoirs and for increasing the number of waterbodies for which the index can be applied, including those that are rich in diatoms belonging to genera included in the list, even if their species are not the same used for the index calibration.

For this purpose, we develop a quality index based on diatom genera and we compare it with an existing index based on diatom species, namely the index EPI-L used in Italy (Marchetto et al., 2013), and we discuss their relative ability to classify lentic waterbodies in quality classes.

\section{METHODS}

During the period 2010-2017, a total of 108 diatom samples were collected from 64 lakes in Italy (Tab. 1), following a common protocol (Buzzi et al., 2014), mainly based on CEN-EN standard 13946 (European Committee for Standardization, 2014). Most of the samples were collected on permanently submerged stones using a toothbrush, while 23 samples were collected on macrophyte stems. Twenty lakes were sampled more than once (Tab. 1). Samples were digested in $\mathrm{H}_{2} \mathrm{O}_{2}$ and $\mathrm{HCl}$, mounted in Naphrax and a minimum of 400 diatom valves were identified under optical microscope at 1000x.

Results from a previous European project (EMERGE: "European Mountain lake Ecosystems: Regionalisation, diaGnostic \& socio-economic Evaluation") allowed the addition of further 16 epilithic samples, collected in 2001 in high mountain lakes with moderate to high alkalinity (higher than $0.2 \mathrm{meq} \mathrm{L}^{-1}$ ) with a very similar protocol (Marchetto et al., 2009). To avoid the overrepresentation of more intensively sampled lakes, in this study we used the mean species abundance for each lake where several samples were available. The complete data set is available at: http://www.ise.cnr.it/products/datasets.

The diatom species counts were entered into OMNIDIA version 5.3 (Lecointe et al., 1993), a diatom database and indices calculation tool. The following indices, commonly used for lake or river quality assessment in Europe, were calculated: Biological Diatom Index (BDI; Coste, 1999), Pollution Sensitivity Index (IPS: CEMAGREF, 1982), Saprobic Index (SI; Rott et al., 1997), Trophic Index (TI; Rott et al., 1999), and the Trophic Diatom Index (TDI; Kelly and Whitton, 1995). The EPI-L index (Marchetto et al., 2013) was calculated using the tool available at: http://www.ise.cnr.it/it/wfd

Species occurring with a higher abundance than $1 \%$ in less than 3 lakes or never reaching a minimum abundance of $3 \%$ in any sample were discarded.

The EPI-L index was used for testing the effect of different taxonomical resolution. For this purpose, the index was recalibrated using the present data set, and excluding species occurring with a higher abundance than $1 \%$ in less than 3 lakes or never reaching a minimum abundance of $3 \%$ in any sample.

The calibration follows the procedure used by Marchetto et al. (2013) and summarised here. For each $i$ th remaining species, a trophic weight $\left(p^{\prime}\right)$ was obtained by the average of the logarithm of the epilimnetic total phosphorus concentration (TP, in $\mu \mathrm{g} \mathrm{L}^{-1}$ ), weighted by the abundance of that species in each $j$-th lake $(a)$.

$p_{i}^{\prime}=\frac{\sum_{j} a_{j} \log _{10} T P_{j}}{\sum_{j} a_{j}}$

The indicator value $(v)$ was obtained as the inverse of the average of the squared differences between the trophic weight of the species and the epilimnetic total phosphorus concentration in each $j$-th lake, weighted by the abundance of that species in the $\mathrm{j}$-th lake itself. Indicator values higher than 30 were replaced with 30 .

$v_{i}=\frac{\sum_{j} a_{j}}{\sum_{j} a_{j}\left(T P_{j}-p^{\prime} i\right)^{2}}$

The re-calibrated EPI-L index (EPI-L $\left.\mathrm{L}_{\text {species }}\right)$ was then calculated on the basis of the relative abundance $i$-th species using the following formula:

$$
E P I-L_{\text {species }}^{\prime}=4-2 \frac{\sum_{i} a_{i} p^{\prime}{ }_{i} v_{i}}{\sum_{i} a_{i} v_{i}}
$$

The index value was not calculated for those lakes for which the sum of the relative abundance of the discarded species was higher than $30 \%$

The trophic value of each species was then corrected using a linear regression of the newly calculated index values for all lakes against the original EPI-L values.

$$
E P I-L=m E P I-L_{\text {species }}^{\prime}+n
$$

The slope and intercept values of the regression equation were used to rescale the trophic weights:

$$
p=\frac{4-4 m+2 m p^{\prime}-n}{2}
$$

Rescaling species optima (Marchetto, 1994) was used to obtain EPI-L'values close to the original EPI-L in order 
Tab. 1. List of the considered lakes.

\begin{tabular}{|c|c|c|c|c|c|c|}
\hline Lake & Longitude $\left({ }^{\circ} \mathrm{E}\right)$ & Latitude $\left({ }^{\circ} \mathbf{N}\right)$ & Altitude (m asl) & Alkalinity & Mean TP & No. of samples \\
\hline Albano & 41.745 & 12.676 & 293 & $\mathrm{H}$ & 20 & 1 \\
\hline Alserio & 45.785 & 9.213 & 280 & $\mathrm{H}$ & 8 & 1 \\
\hline Annone (W basin) & 45.817 & 9.333 & 224 & $\mathrm{H}$ & 29 & 1 \\
\hline Antholzer See & 46.886 & 12.166 & 1640 & M & 4 & 1 \\
\hline Antrona & 46.054 & 8.091 & 1083 & M & 5 & 1 \\
\hline Aplanersee & 46.449 & 10.874 & 2367 & M & 3 & 1 \\
\hline Avigliana & 45.065 & 7.387 & 352 & $\mathrm{H}$ & 12 & 3 \\
\hline Baratz & 40.683 & 8.224 & 32 & $\mathrm{H}$ & 60 & 1 \\
\hline Bidighinzu & 40.557 & 8.662 & 330 & $\mathrm{H}$ & 100 & 1 \\
\hline Bilancino & 43.978 & 11.281 & 252 & $\mathrm{H}$ & 14 & 1 \\
\hline Boden Inferiore & 46.442 & 8.453 & 2334 & $\mathrm{M}$ & 4 & 1 \\
\hline Boden Superiore & 46.439 & 8.453 & 2343 & M & 4 & 1 \\
\hline Bolsena & 42.583 & 11.933 & 305 & $\mathrm{H}$ & 22 & 4 \\
\hline Bracciano & 42.117 & 12.233 & 164 & $\mathrm{H}$ & 16 & 1 \\
\hline Caldonazzo & 46.033 & 11.243 & 450 & $\mathrm{H}$ & 7 & 1 \\
\hline Campo & 46.129 & 8.131 & 2293 & M & 4 & 1 \\
\hline Candia & 45.324 & 7.912 & 227 & $\mathrm{H}$ & 16 & 3 \\
\hline Capezzone & 45.941 & 8.210 & 2100 & $\mathrm{M}$ & 4 & 1 \\
\hline Cavazzo & 46.333 & 13.077 & 195 & $\mathrm{H}$ & 3 & 2 \\
\hline Cavedine & 46.000 & 10.951 & 241 & $\mathrm{H}$ & 17 & 1 \\
\hline Chiusi & 43.055 & 11.962 & 251 & $\mathrm{H}$ & 32 & 1 \\
\hline Cuga & 40.613 & 8.464 & 642 & M & 24 & 1 \\
\hline Endine & 45.778 & 9.938 & 334 & $\mathrm{H}$ & 15 & 1 \\
\hline Fusine Inferiore & 46.482 & 13.669 & 924 & $\mathrm{H}$ & 3 & 1 \\
\hline Fusine Superiore & 46.477 & 13.668 & 929 & $\mathrm{H}$ & 4 & 1 \\
\hline Garda & 45.667 & 10.700 & 133 & $\mathrm{H}$ & 9 & 1 \\
\hline Garlate & 45.821 & 9.406 & 198 & $\mathrm{H}$ & 12 & 1 \\
\hline Grande di Monticchio & 40.930 & 15.610 & 656 & $\mathrm{H}$ & 87 & 1 \\
\hline Grünsee & 46.609 & 12.009 & 2043 & $\mathrm{H}$ & 2 & 1 \\
\hline Haidersee & 46.757 & 10.532 & 1449 & M & 13 & 1 \\
\hline Karersee & 46.426 & 10.703 & 1519 & $\mathrm{H}$ & 3 & 1 \\
\hline Klammsee & 46.982 & 12.128 & 2258 & $\mathrm{H}$ & 4 & 1 \\
\hline Kratzbergersee & 46.705 & 11.286 & 2119 & M & 4 & 1 \\
\hline Ledro & 45.878 & 10.751 & 655 & $\mathrm{H}$ & 9 & 1 \\
\hline Levico & 46.014 & 11.278 & 440 & $\mathrm{H}$ & 5 & 1 \\
\hline Liscia & 40.994 & 9.244 & 178 & M & 29 & 1 \\
\hline Lungo & 42.475 & 12.849 & 371 & $\mathrm{H}$ & 48 & 2 \\
\hline Maggiore & 45.950 & 8.667 & 194 & M & 7 & 2 \\
\hline Martignano & 42.115 & 12.303 & 207 & $\mathrm{H}$ & 15 & 3 \\
\hline Massaciuccoli & 43.833 & 10.333 & 2 & $\mathrm{H}$ & 21 & 1 \\
\hline Matogno & 46.251 & 8.401 & 2067 & M & 4 & 1 \\
\hline Mergozzo & 45.956 & 8.463 & 194 & M & 4 & 2 \\
\hline Mezzano & 42.631 & 11.765 & 455 & $\mathrm{H}$ & 17 & 1 \\
\hline Mezzola & 46.199 & 9.441 & 199 & M & 22 & 2 \\
\hline Milchsee & 46.726 & 11.072 & 2540 & M & 3 & 1 \\
\hline Molveno & 46.123 & 10.959 & 823 & M & 4 & 1 \\
\hline Montepulciano & 43.090 & 11.920 & 249 & $\mathrm{H}$ & 90 & 1 \\
\hline Monterosi & 42.205 & 12.294 & 237 & $\mathrm{H}$ & 55 & 1 \\
\hline Morasco & 46.423 & 8.395 & 1815 & $\mathrm{H}$ & 3 & 1 \\
\hline Nemi & 41.714 & 12.703 & 318 & $\mathrm{H}$ & 27 & 1 \\
\hline Orta & 45.817 & 8.400 & 290 & M & 5 & 1 \\
\hline Paione Inferiore & 46.169 & 8.191 & 2002 & M & 3 & 1 \\
\hline Paione medio & 46.172 & 8.192 & 2147 & M & 6 & 1 \\
\hline Palù & 46.199 & 9.868 & 1925 & M & 5 & 2 \\
\hline
\end{tabular}


Table 1. Continued from previous page.

\begin{tabular}{|c|c|c|c|c|c|c|}
\hline Lake & Longitude ( $\left({ }^{\circ} \mathbf{E}\right)$ & Latitude $\left({ }^{\circ} \mathrm{N}\right)$ & Altitude (m asl) & Alkalinity & Mean TP & No. of samples \\
\hline Panelatte & 46.203 & 8.458 & 2063 & M & 7 & 1 \\
\hline Paterno & 42.382 & 13.014 & 617 & $\mathrm{H}$ & 40 & 1 \\
\hline Pattada & 40.575 & 9.167 & 561 & M & 50 & 1 \\
\hline Piano & 46.037 & 9.162 & 276 & $\mathrm{H}$ & 14 & 1 \\
\hline Piccolo di Avigliana & 45.054 & 7.392 & 356 & $\mathrm{H}$ & 70 & 1 \\
\hline Piccolo di Monticchio & 40.932 & 15.619 & 658 & $\mathrm{H}$ & 23 & 1 \\
\hline Piediluco & 42.529 & 12.751 & 368 & $\mathrm{H}$ & 33 & 2 \\
\hline Pojala & 46.329 & 8.335 & 2305 & M & 5 & 1 \\
\hline Posada & 40.639 & 9.608 & 43 & M & 45 & 1 \\
\hline Predil & 46.417 & 13.567 & 965 & $\mathrm{H}$ & 3 & 1 \\
\hline Pusiano & 45.802 & 9.273 & 259 & $\mathrm{H}$ & 11 & 2 \\
\hline Ragogna & 46.175 & 13.003 & 188 & $\mathrm{H}$ & 13 & 2 \\
\hline Ripasottile & 42.475 & 12.815 & 371 & $\mathrm{H}$ & 60 & 2 \\
\hline Salto & 42.279 & 13.024 & 535 & $\mathrm{H}$ & 49 & 2 \\
\hline Scanno & 41.923 & 13.864 & 922 & $\mathrm{H}$ & 21 & 2 \\
\hline Segrino & 45.829 & 9.267 & 374 & $\mathrm{H}$ & 11 & 1 \\
\hline Sirio & 45.485 & 7.885 & 271 & $\mathrm{H}$ & 18 & 3 \\
\hline Sos Canales & 40.555 & 9.313 & 711 & M & 28 & 1 \\
\hline Südlichter Kofferrastersee & 46.576 & 10.940 & 2405 & M & 6 & 1 \\
\hline Tenno & 45.939 & 12.452 & 570 & $\mathrm{H}$ & 3 & 1 \\
\hline Timmelsschwarzsee & 46.928 & 11.163 & 2514 & M & 3 & 1 \\
\hline Toblino & 46.063 & 10.967 & 245 & $\mathrm{H}$ & 24 & 1 \\
\hline Trasimeno & 43.150 & 12.100 & 259 & $\mathrm{H}$ & 60 & 2 \\
\hline Turano & 42.232 & 12.941 & 540 & $\mathrm{H}$ & 62 & 3 \\
\hline Vico & 42.317 & 12.167 & 507 & $\mathrm{H}$ & 21 & 1 \\
\hline Viverone & 45.401 & 8.051 & 230 & $\mathrm{H}$ & 30 & 3 \\
\hline
\end{tabular}

$\mathrm{H}$, alkalinity $>1 \mathrm{mmol}_{\mathrm{C}} \mathrm{L}^{-1} ; \mathrm{M}$, alkalinity between 0.2 and $1 \mathrm{mmol}_{\mathrm{C}} \mathrm{L}^{-1}$; TP, total phosphorus $\left(\mu \mathrm{g} \mathrm{L}^{-1}\right)$.

to avoid differences in lake classification between EPI-L and EPI-L' and to avoid the need of defining new boundaries between the quality classes for the revised index.

The same procedure was then used considering diatom genera instead of species to obtain a second index, named EPI-L' ${ }_{\text {genera }}$.

\section{RESULTS}

All calculated diatom indices resulted significantly correlated to the trophic gradient, expressed as the mean epilimnetic total phosphorus concentration (Fig. 1), but the high correlation between EPI-L and TP is an artefact, due to the use in this paper of the same samples used for the calibration of the index.

Lakes with low phosphorous concentration can be distinguished from lakes with high concentration on the basis of the EPI-L index. On the contrary, in spite of the good correlation, for all other indices there is a large overlap between the values calculated for lakes with high and low trophic status. For this reason, EPI-L was selected for the quality assessment of Italian lakes, and is also used in this study.

Trophic weights and indicator values were obtained for 90 species and are reported in Tab. $\mathrm{S} 1$ in the supplementary material, after rescaling $(m=1.0761, n=$ 0.0472). The new index (EPI-L' ${ }_{\text {species }}$ ) resulted strongly correlated ( $r=0.874, \mathrm{P}<0.001)$ with the trophic gradient, expressed as the decimal logarithm of the mean concentration of total phosphorus (Fig. 2a). Repeating the calibration for 34 genera, the index (EPI-L' genera) also resulted strongly correlated $(r=0.683, \mathrm{P}<0.001)$ with the trophic gradient, expressed as the decimal logarithm of the mean concentration of total phosphorus, but some outliers were evident (Fig. 2b).

Indeed, for most genera, the trophic scores of the species lye in a relatively small range (Fig. 3), so that the use of an index based on lower taxonomic resolution should be possible. However, this was not the case for the genera Achnanthidium, Discostella, Encyonema, Eunotia, Fragilaria and Pantocsekiella (Fig. 3). We suspected that the presence in these genera of species with outlying trophic score could lead to a weaker performance of the 
index when the taxonomic resolution would be reduced. For this reason, beside an index based on diatom species $\left(\right.$ EPI- $\left.\mathrm{L}_{\text {species }}\right)$ and one based on diatom genera (EPI- $\left.\mathrm{L}_{\text {genera }}\right)$, we developed a hybrid index based on more homogeneous group (EPI- $\left.\mathrm{L}_{\text {taxa }}\right)$.

For calibrating this latter index, we separated the relative abundance of Achanthidium lineare W.Smith, Discostella stelligera (Cleve \& Grunow) Houk \& Klee, Encyonema caespitosum Kützing and E. ventricosum (C.Agardh) Grunow, Eunotia exigua (Brébisson ex Kützing) Rabenhorst and Pantocsekiella ocellata
(Pantocsek) K.T.Kiss \& E.Ács from the rest of their respective genera. In the case of Fragilaria, we considered three groups: the first formed by F. crotonensis Kitton, the second by F. tenera (W.Smith) Lange-Bertalot and $F$. tenera var. nanana (Lange-Bertalot) LangeBertalot \& S.Ulrich, and the third including all other Fragilaria species.

Trophic weights and indicator values were then obtained for 40 taxa (genera and species groups) and are reported in table $\mathrm{S} 2$, after rescaling $(m=1.2108, n=-$ $0.1981)$. The correlation of this index, named EPI-L' ${ }_{\text {taxa }}$,
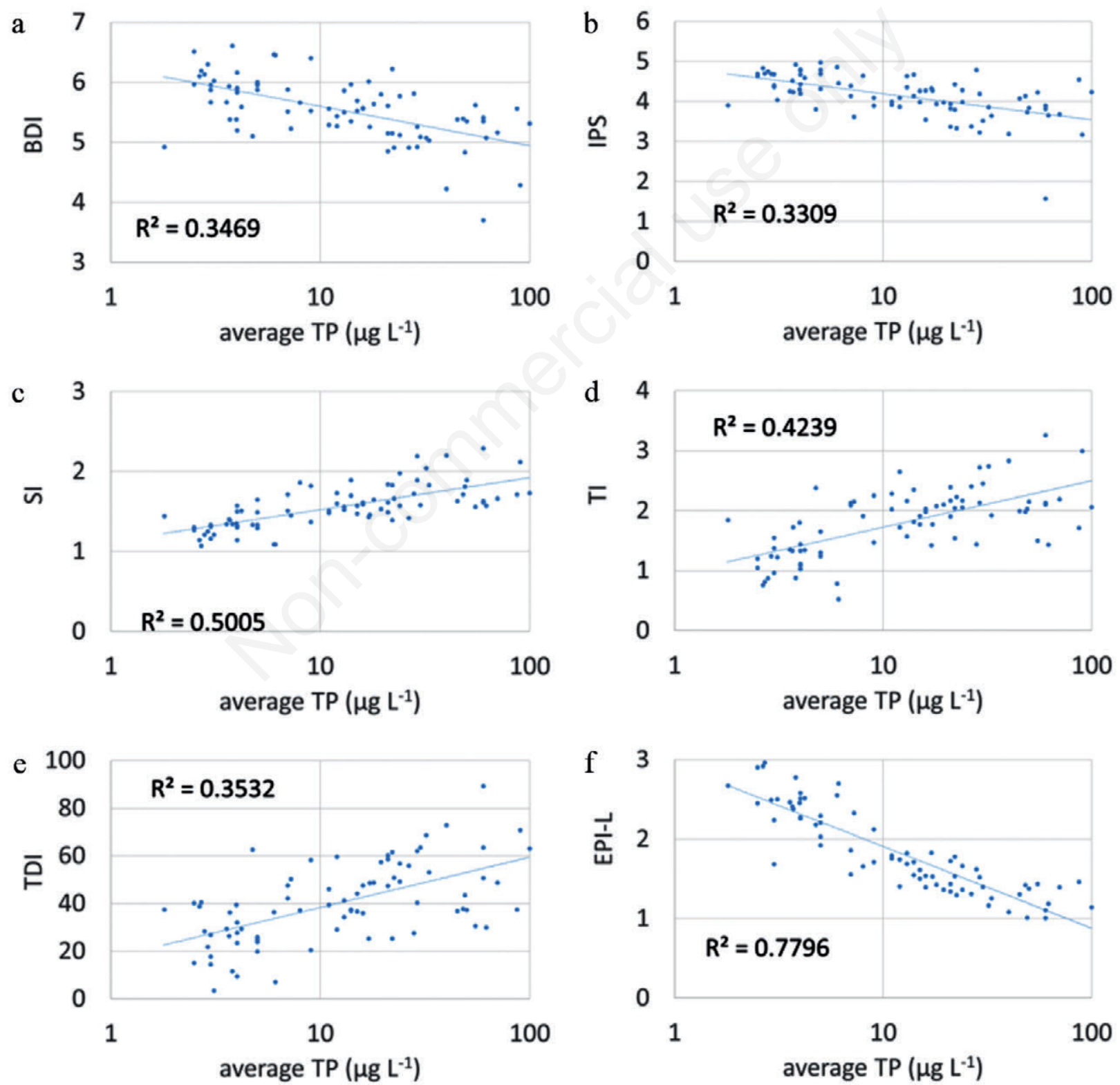

Fig. 1. Relationship between some selected diatom-based quality index and the average annual total phosphorus concentration for the lakes used in this study. 
with the trophic gradient was only slightly stronger $(r=0.689, \mathrm{P}<0.001)$ than the one based on genera (Fig. 2c). Comparing EPI-L ${ }_{\text {taxa }}$ with the original EPI-L, their values compare well, with a median absolute difference of 0.02 (Fig. 2d).

\section{DISCUSSION}

In our database, the use of metrics developed for rivers for the assessment of ecological status in lakes resulted in slight correlation with the trophic gradient, probably because some diatom species do have distinct preferences for lakes over rivers (Kelly et al., 2014). Among the metrics specifically developed for lakes, L-TDI (Bennion et al., 2014) could not be correctly applied to our data set, as in no lakes the abundances of the species included in the L-TDI species list accounted for more than $70 \%$ of the total diatom counts. Therefore, the correlation between LTDI and the logarithm of the total phosphorus concentration was low $(r=0.44)$. On the contrary, Rott's (1999) TI index was well correlated with the trophic gradient ( $r=0.64)$, but it could only be used to evaluate the ecological quality of 52 out of 80 lakes in our database.

For this reason, Marchetto et al. (2013) developed a specific index for Italian lakes and reservoirs (EPI-L), in order to have a species list reflecting the composition of diatom assemblages in Italy and a good relationship with the trophic gradient in these lakes, which can be applied to 73 lakes in our data set. However, we expect that in a large-scale monitoring of all Italian lakes and reservoirs, some species not included in the EPI-L list will be found, making impossible to assess the ecological quality of some lakes or reservoirs. To allow the classification of those water bodies, we propose to use a revised index that does not require diatom determination at the species level. The indices based on species and on taxa was able to classify 74 out of 80 lakes, while the index based on genera was able to classify 79 out of 80 lakes.

Our results substantially confirm the finding of Bennet et al. (2014), who discussed the performance of diatom indices using different taxonomic resolution. They found large performance differences between species- and
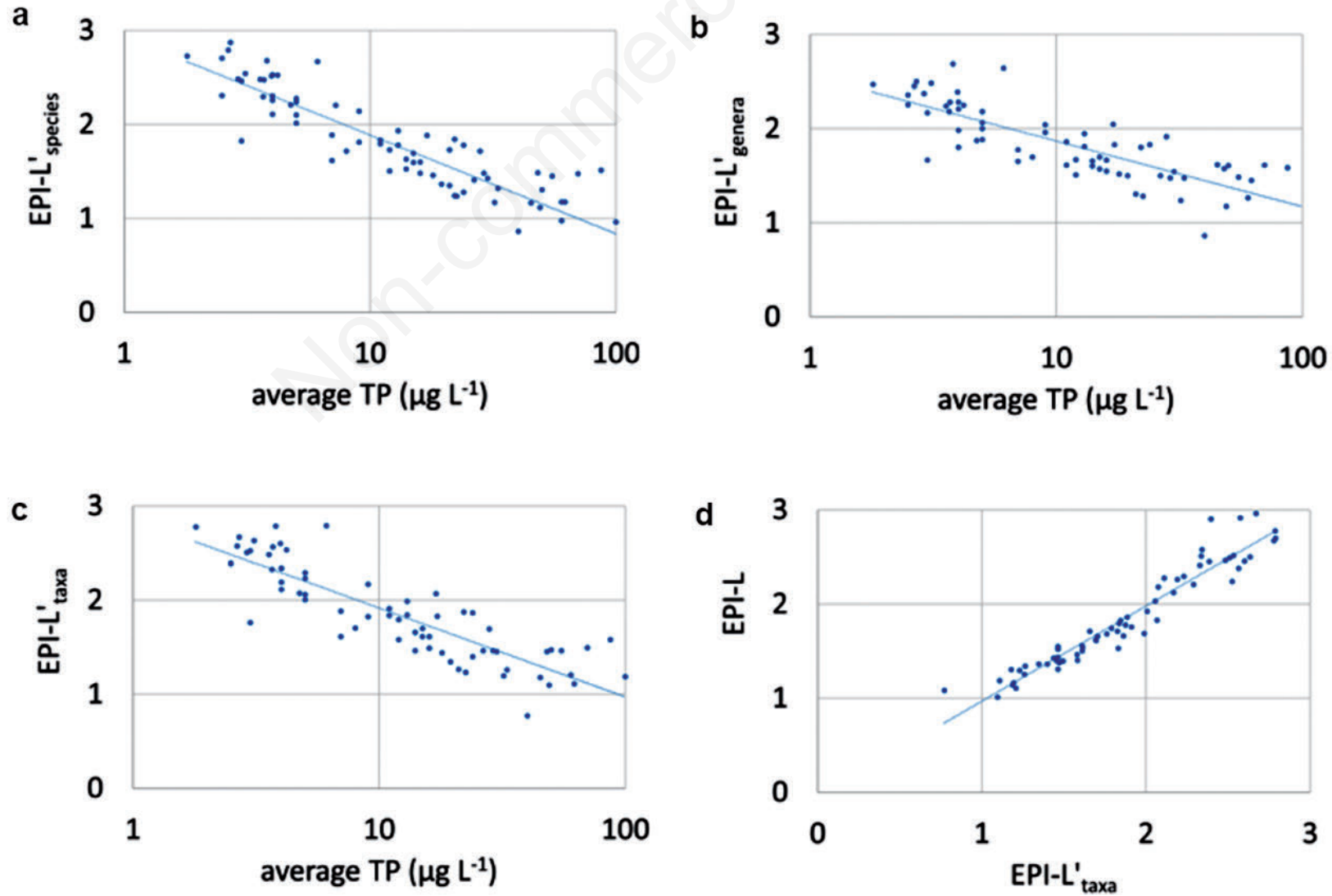

Fig. 2. Scatter plot of mean EPI-L', ${ }_{\text {species }}(a), E P I-L_{\text {genera }}$ (b) and EPI-L' ${ }_{\text {taxa }}$ (c) vs the average annual total phosphorus concentration, and comparison of EPI-L ${ }_{\text {taxa }}$ with the original EPI-L for the lakes used in this study (d). 
genus-based indices calibrated along an acidity gradient, However, the differences were small when comparing indices calibrated along a trophic gradient.

Following the WFD, the boundaries between quality classes should be defined through intercalibration exercises, to assure that in the same ecoregion class boundaries are shared by all Member states. In the case of lake diatoms, the intercalibration exercise (Kelly et al., 2014) was performed comparing the methods used in different countries with a common metric, namely the Trophic index (Rott, 1999), which requires diatom counts at the species level. For this reason, if the EPI- $\mathrm{L}_{\text {genera }}$ or EPI- $\mathrm{L}_{\text {taxa }}$ will be used for WFD-compliant ecological assessment, a species-level diatom determination is still needed for the data set used for the intercalibration exercise.

Based on the intercalibration exercise (Marchetto, 2014), the boundaries between the "high" and "good" quality classes were set to an EPI-L value of 1.702 for

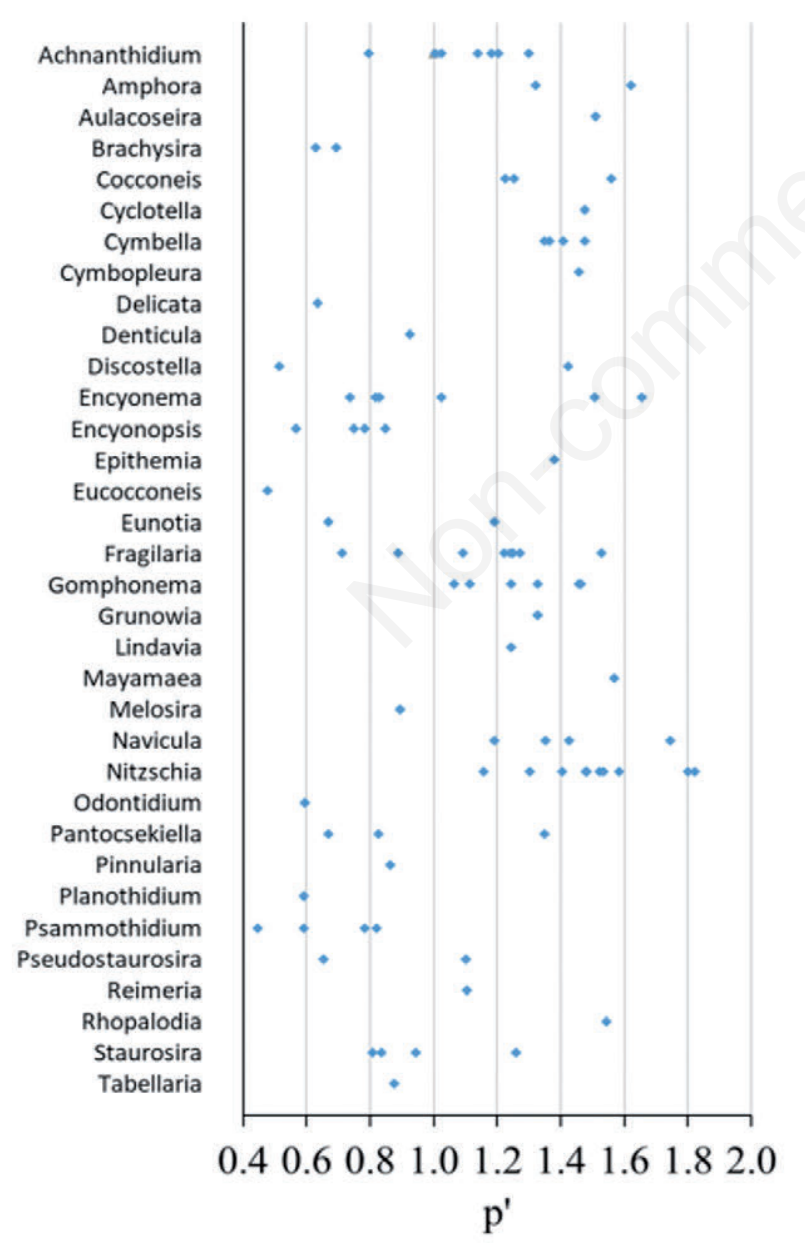

Fig. 3. Distribution of the trophic scores ( $\left.p^{\prime}\right)$ for species belonging to the same genus. deep lakes and 1.845 for shallow lakes, while the boundaries between "good" and "moderate" ecological quality was set to 1.135 for deep lakes and 1.230 for shallow lakes.

In this study, most lakes fell in the same quality class

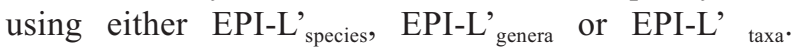
Differences in lake classification between EPI-L' EPI-L' ${ }_{\text {taxa }}$ and between EPI-L' ${ }_{\text {genera }}$ and EPI-L' ${ }_{\text {taxa }}$ were only found for two lakes, for which the index value lied close to the boundary value. However, the number of classification mismatches was higher (6) in the case of EPI- $\mathrm{L}_{\text {genera }}$. These results are similar to those obtained by Bigler et al. (2010) in a similar study: they also found that reducing taxonomic resolution within the Achnanthidium minutissimum species complex from a series of subgroups to a single group led to changes in lake quality classification using the IPS index for a small number of lakes, only in cases when the index value was close to the class boundary.

\section{CONCLUSIONS}

Diatom-based indices are widely used in Europe for assessing lake ecological quality. Most of them are based on a list of indicator values assigned to diatom species. They cannot be used when a significant proportion of diatom found in a given lake are not included in their species list.

To reduce this problem, we tested the possibility to use an index based on diatom genera. However, we found that the reduction in taxonomic resolution led to an increase in classification mismatches. The results of this exercise indicate that the index based on genera can be improved in classification ability splitting some genera, when the species belonging to them have markedly different trophic preferences. The resulting index seems to compare with an index requiring diatom determination to the species level.

Finally, if adequate rescaling of the trophic scores is applied, we propose that the genera trophic scores and indicator values can be used together with the species ones, when individual specimen cannot be assigned to a given species, or when their species is not included in the species list of the original index.

\section{ACKNOWLEDGMENTS}

We warmly acknowledge Dr. Mattia Azzella for providing samples of the volcanic lakes in Central Italy and the following data providers: Renate Abler, Berta Thaler (Provincial Environmental Agency of Bolzano), Arianna Macor, Raffaella Zorza (Regional Environmental Agency of Friuli Venezia Giulia), Simona Musazzi (CNR- 
ISE), Stefania Balsamo (Italian Institute for Environmental Protection and Research), Laura Mancini, Stefania Marcheggiani, Camilla Puccinelli, Claudia Vendetti (National Institute of Health), Chiara Agostinelli, Andrea Beghi, Fabio Buzzi, Elisa Carena, Marco Fioravanti, Riccardo Formenti, Matteo Galbiati, Filippo Galimberti (Regional Environmental Agency of Lombardia), Pierluigi Fogliati, Arianna Nicola (Regional Environmental Agency of Piemonte), Silvia Costaraoss, Sabrina Pozzi, Paola Testa (Provincial Environmental Agency of Trento), Susanna Cavalieri, Federica Cimoli, Giovanna Marchi, Chiara Rustighi (Regional Environmental Agency of Toscana), Stefania Bracchi, Isa Crescentini, Valentina Della Bella, Margerita Di Brizio, Rosalba Padula, Egiziana Rinaldi (Regional Environmental Agency of Umbria).

High mountain diatom samples were collected within the EMERGE project ("European Mountain lake Ecosystems: Regionalisation, diaGnostic \& socioeconomic Evaluation"), funded by the European Union (Contract EVK1-CT-1999-00032) under the $5^{\text {th }}$ Framework Programme.

\section{REFERENCES}

Bennett JR, Sisson DR, Smol JP, Cumming BF, Possingham HP, Buckley YM, 2014. Optimizing taxonomic resolution and sampling effort to design cost-effective ecological models for environmental assessment. J. Appl. Ecol. 51:1722-1732.

Bennion H, Kelly MG, Juggins S, Yallop ML, Burgess A, Jamieson BJ, Krokowski J, 2014. Assessment of Ecological status in UK lakes using benthic diatoms. Freshwat. Sci. 33:6 39-654.

Bigler C, Gälman V, Renberg I, 2010. Numerical simulations suggest that counting sums and taxonomic resolution of diatom analyses to determine IPS pollution and ACID acidity indices can be reduced. J Appl Phycol 22:541-548.

Buzzi F, Mancini L, Vendetti C, Puccinelli C, Marcheggiani S, Marchetto A, 2014. [Protocollo di campionamento ed analisi delle diatomee bentoniche dei laghi e degli invasi], p. 215233. In: S. Balzamo and C. Martone (eds.), [Metodi biologici per le acque superficiali interne].[Book in Italian]. ISPRA, Manuali e Linee Guida 111/2014.

CEMAGREF, 1982. [Etude des méthodes biologiques d'appréciation quantitative de la qualité des eaux, in Bassin Rhône-Mediterrannée-Corse].[Book in French]. CSIRO: pp. 218.

European Committee for Standardization, 2014. Water quality Guidance for the routine sampling and preparation of benthic diatoms from rivers and lakes. European Standard 13946.

Coste M, Boutry S, Tison-Rosebery J, Delmas F. 2009. Improvements of the Biological Diatom Index (BDI): description and efficiency of the new version (BDI-2006). Ecol. Indic. 9:621-650.

Descy JP. 1979. A new approach to water quality estimation using diatoms. Nova Hedwig 64:305-323.

European Union, 2000. Directive 2000/60/EC of the European
Parliament and of the Council of 23 October 2000 establishing a framework for community action in the field of water policy. Off. J. (L 327), 22 (2000), p. 12

Flemish Environment Agency, 2009. Biological assessment of the natural, heavily modified and artificial surface water bodies in Flanders according to the European Water Framework Directive. Vlaamse Milieumaatschappij, Erembodegem, Brussels.

Kelly M G, Whitton BA, 1995. The trophic diatom index: a new index for monitoring eutrophication in rivers. J. Appl. Phycol. 7:433-444.

Kelly M, Urbanic G, Acs E, Bennion H, Bertrin V, Burgess A, Denys L, Gottschalk S, Kahlert M, Karjalainen SM, Kennedy B, Kosi G, Marchetto A, Morin S, PicinskaFałtynowicz J, Poikane S, Rosebery J, Schoenfelder I, Schoenfelder J, Varbiro G. 2014. Comparing aspirations: intercalibration of ecological status concepts across European lakes for littoral diatoms. Hydrobiologia 734:125141.

Kelly MG, Birk S, Willby NJ, Denys L, Drakare S, Kahlert M, Karjalainen SM, Marchetto A, Pitt J-A, Urbanič G, Poikane S, 2016. Redundancy in the ecological assessment of lakes: Are phytoplankton, macrophytes and phytobenthos all necessary? Sci. Total Environ. 568:594-602.

Lecointe C, Coste M, Prygiel J, 1993. 'Omnidia': Software for taxonomy, calculation of diatom indices and inventories management. Hydrobiologia 269/270:509-513.

Lenoir A, Coste M, 1996. Development of a practical diatom index of overall water quality applicable to the French National Water Board network. In: B.A. Whitton and E. Rott (eds.), Use of algae for monitoring rivers II. Institute of Botanic, University of Innsbruck.

Marchetto A, 1994. Rescaling species optima estimated by weighted averaging. J. Paleolimnol. 12:155-162.

Marchetto A, 2014. Report on fitting the Italian national method for the evaluation of the ecological quality of lake waterbodies using benthic diatoms (EPI-L) in the "phytobenthos cross-GIG" intercalibration exercise. Report CNR ISE, 01.14, 18 pp. http://www.ise.cnr.it/it/wfd

Marchetto A, Rogora M, Boggero A, Musazzi S, Lami A, Lotter AF, Tolotti M, Thies H, Psenner R, Massaferro J, Barbieri A, 2009. Response of Alpine lakes to major environmental gradients, as detected through planktonic, benthic and sedimentary assemblages. Advanc. Limnol. 62:419-440.

Marchetto A, Agostinelli C, Alber R, Beghi A, Balsamo S, Bracchi S, Buzzi F, Carena E, Cavalieri S, Cimoli F, Costaraoss S, Crescentini I, Della Bella V, Di Brizio M, Fioravanti M, i Fogliati P, Formenti R, Galbiati M, Galimberti F, Macor A, Mancini L, Marcheggiani S, Marchi G, Musazzi S, Nicola A, Padula R, Pozzi S, Puccinelli C, Rinaldi E, Rustighi C, Testa P, Thaler B, Vendetti C, Zorza $\mathrm{R}, 2013$. [Indice per valutazione della qualità delle acque lacustri italiane a partire dalle diatomee epifitiche ed epilitiche (EPI-L)], p. 75-92. In: A. Marchetto (ed.), [Indici per la valutazione della qualità ecologica dei laghi].[Report in Italian]. Report CNR-ISE 02-13. Available from: http://www.ise.cnr.it/it/wfd

Round FE, Crawford RM, Mann DG, 1990. Diatoms: Biology and morphology of the genera. Cambridge University Press, p. 747. 
Rott E, Hofmann G, Pall K, Pfister P, Pipp E, 1997. Indikationslisten für Aufwuchsalgen. Teil 1. SaprobielleIndikation. Bundesministeriumfür Land- und Forstwirtschaft, Wien. 1-73.

Rott E, 1999. [Teil 2: Trophieindikation sowie Geochemische Präferenz; Taxonomische und Toxikologische Anmerkungen].[Book in German]. Indikationslisten für Aufwuchsalgen in Österreichischen Fliessgewässern, Wien. Schaumburg J, Schranz C, Hofmann G, Stelzer D, Schneider S, Schmedtje U, 2004. Macrophytes and phytobenthos as indicators of ecological status in German lakes: a contribution to the implementation of the water framework directive. Limnologica 34:302-314.

Schneider SC, Lawniczak AE, Picińska-Faltynowicz J, Szoszkiewicz K, 2012, Do macrophytes, diatoms and nondiatom benthic algae give redundant information? Results from a case study in Poland. Limnologica 42: 04-211.

Sladecek V, 1986. Diatoms as indicators of organic pollution. Acta Hydrochim. Hydrobiol. 14:555-566.

Zelinka M, Marvan P, 1961. [Zur Präzisierung der biologischen klassifikation der Reinheit fließender Gewässer].[Article in German]. Arch. Hydrobiol. 57:389-407. 